\title{
STRUCTURE OF BUTTERFLY COMMUNITY OF ANAIKATTY HILLS, WESTERN GHATS
}

\author{
R. Eswaran ${ }^{1}$ and P. Pramod ${ }^{2}$
}

Salim Ali Centre for Ornithology and Natural History, Anaikatty P.O., Coimbatore, Tamil Nadu 641108, India Email: ${ }^{1}$ eswararaj781@rediffmail.com; ${ }^{2}$ pramodpalakkad@gmail.com (corresponding author)

\begin{abstract}
The community structure of butterflies was studied in the dry deciduous, thorny forest of Anaikatty hills, Western Ghats. Pierid butterflies showed greater abundance, which may be due to the relatively greater abundance of Capparaceae and Caesalpinaceae plants in the area. More species of Nymphalid butterflies were recorded from the area than any other family. Six endemic species and eight protected species listed under the Wildlife (Protection) Act were recorded from the area. The butterfly community did not show much variation between the sampling locations. The conservation value of the whole area is highlighted.
\end{abstract}

KEYWORDS

Anaikatty, Butterflies, community, Dry deciduous, Nymphalidae, Pieridae, Western Ghats

The Western Ghats biodiversity hotspot harbours 331 species of butterflies. Most of the previous studies on butterflies in Western Ghats were on the diversity and seasonal pattern (Ugarte \& Rodricks, 1960; Larsen, 1987a,b,c, 1988; Asaithambi, 1994). Butterflies are known to follow seasonal pattern of distribution (Kunte, 1997; Arun, 2000). The present study was conducted to record the butterfly community structure in the thorny dry deciduous habitat of Anaikatty hills and understand the representation of the Western Ghats butterfly fauna.

\section{Study Area}

Anaikatty Hills (76 $\left.39^{\prime}-79^{0} 47^{\prime} \mathrm{E} \& 11^{0} 5^{\prime}-11^{0} 31^{\prime} \mathrm{N}\right)$, which falls under the Nilgiri Biosphere Reserve, is located in the Anaikatty Reserve Forest in Coimbatore district of Tamil Nadu, India (Fig. 1). The area receives an average rainfall of $668 \mathrm{~mm}$ per year recorded over the last 10 years. Maximum temperature varies from 29 to 37 degrees. Trees, such as Albizia amara, Albizia lebbeck, Acacia leucophloea, Acacia polyacantha, Ziziphus mauritiana, Chloroxylon swietenia and Tamarindus indica are the dominant trees in this area. Dominant shrubs are Cassia auriculata, Cassia fistula, Capparis grandis, C. roxburghii, C. grandiflora, C. sepiaria, Flacourtia indica, Elaeodendron glaucam, Clausina heptaphylla, Randia dumetorum, Premna tomentosa and Pavetta indica. Lantana camara, Chromolaena odorata and Parthenium hysterophorus are the prominent weeds in the open areas of the landscape.

\section{Methodology}

The method adopted for sampling butterflies was transect count popularly known as 'Pollard walk' following Moore (1975), Pollard et al. (1975), and, Walpole and Sheldon (1999). All the butterflies observed on either side of the transect path up to $5 \mathrm{~m}$ wide were counted, although some lycaenids and some hesperids were difficult to be identified in the field. These were caught by hand net and identified up to the species and released. We followed classification by Ackery (1984) and
Goankar (1996) that classify the butterflies into five major families.

Four separate transect paths were laid in the four physiognomically different natural vegetation of the landscape. Transects were surveyed twice in a month. One-kilometer distance was covered in one-hour duration during the sampling. Thus eight-hour observation was required for getting one month's data. The study period was between March 2002 and February 2003. The butterfly diversity data of the study area was compared with the Western Ghats butterfly fauna to know the efficiency of the sample and the representation of the Western Ghats butterflies from the study area.

The mean, standard deviation, minimum, maximum and coefficient of variation of butterfly abundance in four transects were analysed to know the butterfly abundance similarity and variation in different sampling locations. The relative abundance of the butterflies in the samples was also calculated.

\section{Results}

Seventy-five species of butterflies were recorded during the study period (Table 1). Nymphalidae was the most speciesrich family where as Pieridae formed the most abundant family (Table 2). The number of butterfly species observed fluctuated between 14 and 48 per month, and number of butterflies observed fluctuated between 136 and 3686 per month. The monthly mean abundance of butterflies did not vary much among transects (Table 3). The Common Gull (Cepora nerissa) (Relative abundance $(\mathrm{RA})=0.13$ ) was the most dominant butterfly encountered in one year. Yellow Orange Tip (Ixias pyrine $)(\mathrm{RA}=0.10)$, White Orange Tip (Ixias maurianne) $(\mathrm{RA}=$ 0.09) and Mottled Emigrant (Catopsilia pyranthe) $(\mathrm{RA}=0.08)$ were the next three dominants. Pieridae was the most common family throughout the year followed by Nymphalidae and Papilionidae. All these three families showed an extraordinary peak between October and December.

The species recorded in Anaikatty hills formed 23\% of the Western Ghats butterfly fauna with better representation for Papilionidae $(63 \%)$ and Pieridae (42\%) compared the other families. Anaikatty harbours six endemic species of butterflies. The endemism level varies from southern India to the Indian Subcontinent (Table 1). Two Schedule I species of Wildlife Protection Act, 1972 were recorded from the Anaikatty hills. Five Schedule II species and one Schedule IV species were also recorded from the study area. The butterfly community did not show significant variation in different transects (Table 3).

(C) Zoo Outreach Organisation; www.zoosprint.org Manuscript 1330; Received 04 February 2005; Revised received 27 April 2005; Finally accepted 20 June 2005 ; Date of publication 21 July 2005 August 2005 | ISSN 0971-6378 


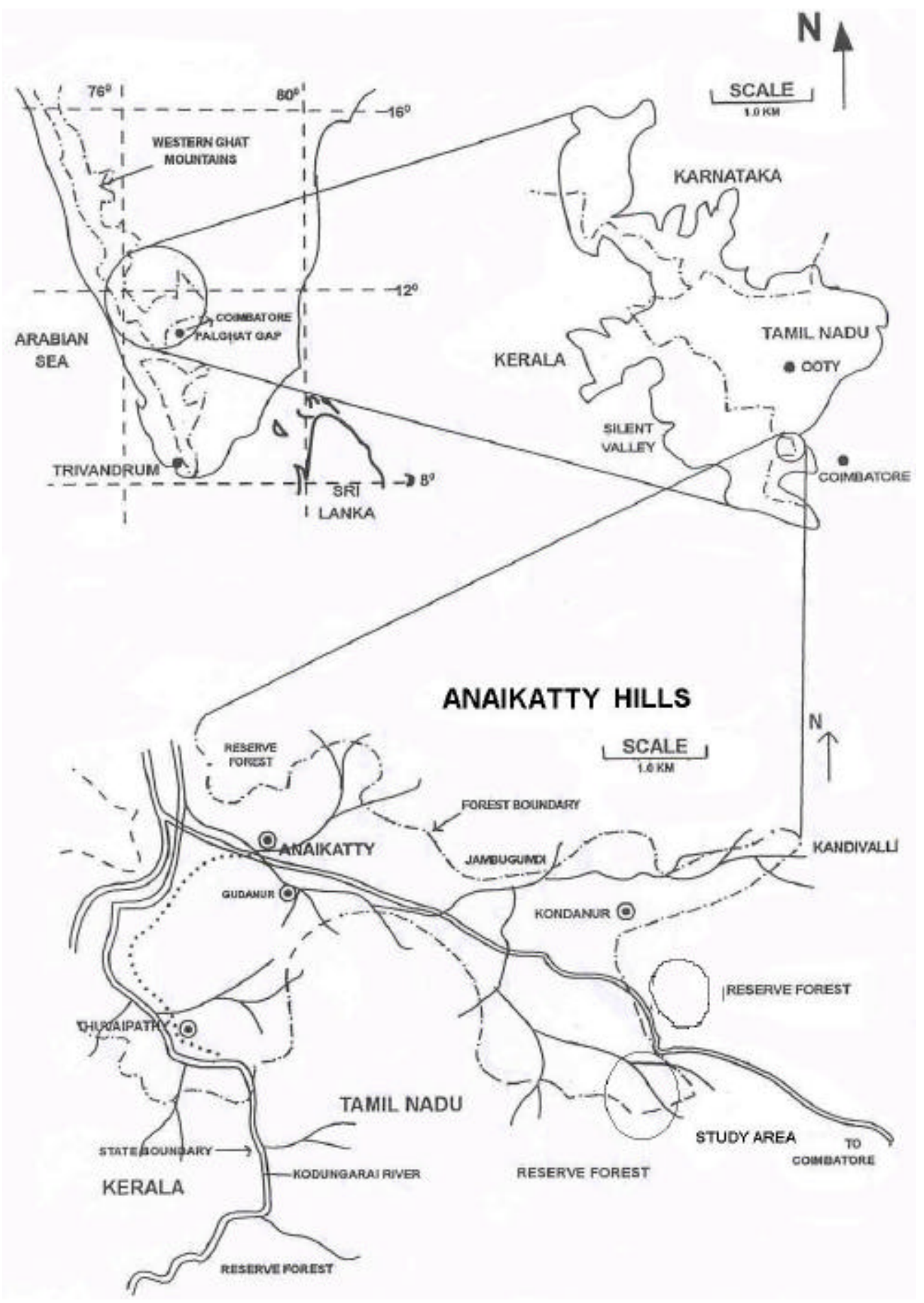

Figure 1. Location of the study area 
Table 1. Checklist of butterflies in Anaikatty hills, Western Ghats

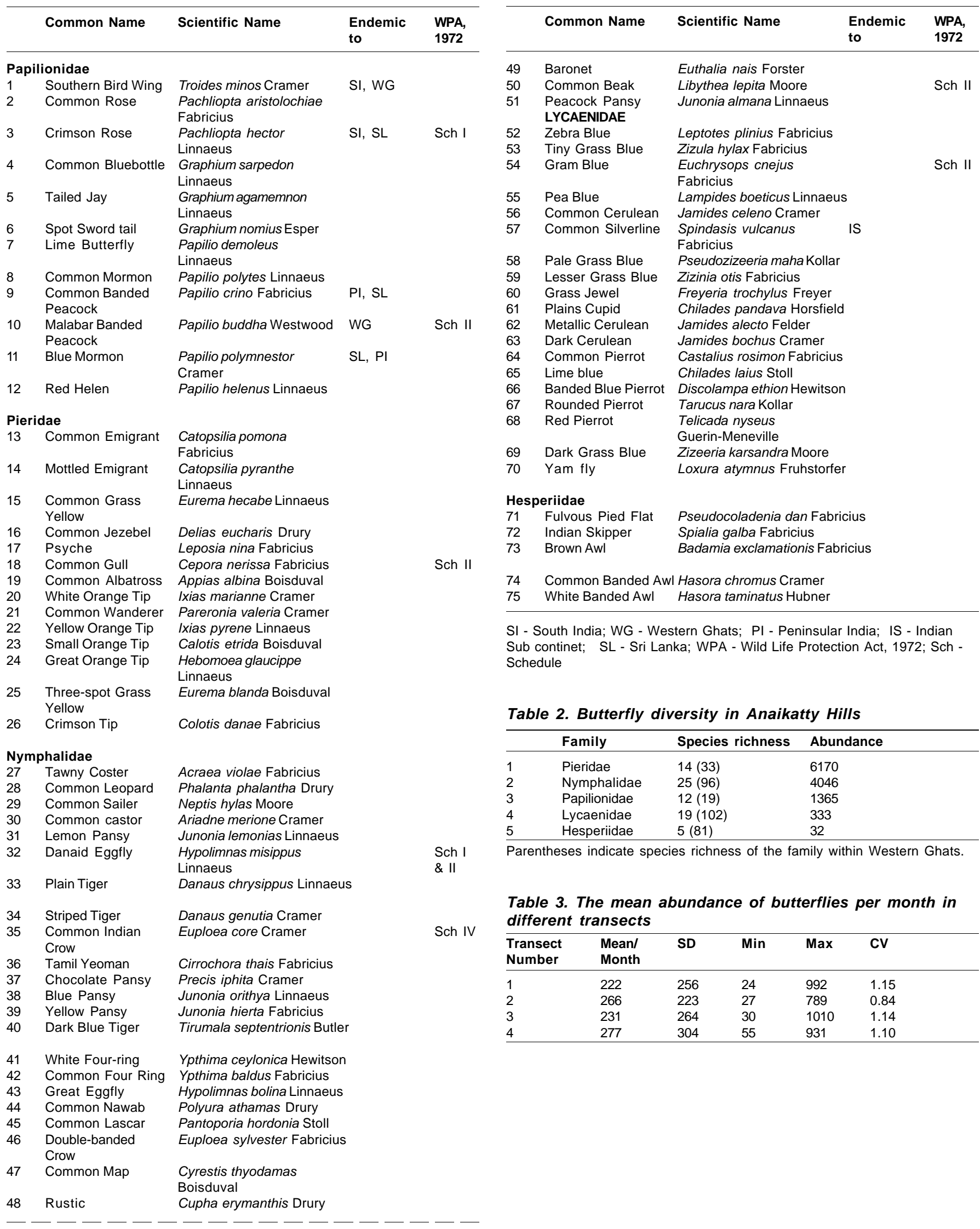




\section{Discussion}

Family Nymphalidae representing the maximum number of species is observed true for the entire region. Earlier reports in the nearby moist deciduous forest in Siruvani (Arun, 2000) and in the evergreen forest of Silent Valley National Park (Mathew \& Rahamathulla, 1993) indicated dominance of Nymphalidae in species richness. Pieridae represented maximum abundance of butterflies in the study area. However, it contradicts with the abundance of nymphalids observed in the evergreen forest of Siruvani hills (Arun, 2000). The reason for this extraordinary abundance of pierid butterflies in the study area can be ascribed to the dominance of their larval food plants in the region. Balasubramanian et al. (2001) reported the dominance of the plants belonging to the genus Capparis, Cassia, Bauhinia, Albizia in the study area, which are the food plants of pierid butterflies. One species, Common Gull (Cepora nerissa) makes all the difference in diversity patterns for Pieridae. Number fluctuations of other species are comparable with the dominant ones of other families. In Nymphalidae also the pattern looks similar with an exception of Dark Blue Tiger (Tirumala septentrionis), whose abundance peaked in October. In Papilionidae two Papilio species, $P$. polytes and $P$. demoleus showed similar trend by peaking in November. These minor differences may be due to the difference in their life history strategies, but to prove it more specific studies are needed.

Representation from the family Hesperiidae was very less compared to the proportion of Western Ghats hesperiid butterflies. It is partly due to the sampling bias, since hesperids exhibit crepuscular habit, i.e., they are active early morning and to a lesser extent, in the evening. They are also seen active in daytime under the shade of the jungle or out in the open during cloudy weather (Wynter-Blyth, 1957; Kunte, 2000). However, the sample data reflects the same trends in composition of species in various families of butterflies of Western Ghats.

We conclude that Anaikatty hills support a pierid dominated butterfly community. The butterfly diversity of the Anaikatty hills is similar to other parts of the Western Ghats reported earlier. The butterfly community did not show much variations between the sampling locations of the study area, hence the whole area can be considered as one unit while planning conservation measures. The fact that the study area harbours significant numbers of endemic and protected butterfly species, also highlight greater conservation importance of the area.

\section{REFERENCES}

Ackery, P.R. (1984). Systematic and faunistic studies on butterflies, pp.9-21. In: Vane Wright, R.I. and P.R. Ackery (Editor). The Biology of Butterflies. Symposium of the Royal Entomological Society London No. 11. Academic Press.

Arun, P.R. (2000). Seasonality and abundance of insects with special reference to butterflies (Lepidoptera: Rhapalocera) in a moist deciduous forest of Siruvani, Nilgiri Biosphere reserve, South India. Ph.D Thesis submitted to Bharathiar University, Coimbatore, India.

Asaithambi, P. (1994). Butterflies of Mudumalai Wildlife Sanctuary, Tamil Nadu. Zoos' Print 12(11): 1.

Balasubramanian, P., P. Mahendramani and K. Padmapriya (2001). Comparison of plant biodiversity pattern of variously disturbed habitats of Moongilpallam area in the Western Ghats. Report. Salim Ali Centre for Ornithology and Natural History, Coimbatore.

Goankar, H. (1996). Butterflies of Western Ghats, India (including SriLanka): A biodiversity assessment of a threatened mountain system. Report submitted to the Centre for Ecological Sciences, Bangalore (unpublished).

Kunte, K. (1997). Seasonal patterns in butterfly abundance and species diversity in four tropical habitats in northern Western Ghats. Journal of Biosciences 22(5): 593-603.

Kunte, K. (2000). Butterflies of Peninsular India. Universities Press. Hyderabad, 254pp.

Larsen, T.B. (1987a). The butterflies of the Nilgiri mountains of southern India (Lepidoptera: Rhapalocera). Journal of the Bombay Natural History Society 84(1): 26-54.

Larsen, T.B. (1987b). The butterflies of the Nilgiri mountains of southern India (Lepidoptera: Rhapalocera). Journal of the Bombay Natural History Society 84(2): 291-316.

Larsen, T.B. $(\mathbf{1 9 8 7})$ ). The butterflies of the Nilgiri mountains of southern India (Lepidoptera: Rhapalocera). Journal of the Bombay Natural History Society 84(3): 560-584.

Larsen, T.B. (1988). The butterflies of the Nilgiri mountains of southern India (Lepidoptera: Rhapalocera). Journal of the Bombay Natural History Society 85(1): 26-43.

Mathew, G. and V.K. Rahamathulla (1993). Studies on the butterflies of Silent Valley National Park. Entomon 18(3): 185-192.

Moore, N.W. (1975). Butterfly transects in a linear habitat, 19641973. Entomologist's Gazeteer 26: 71-78.

Pollard, E., D.O. Elias, M.J. Skelton and J.A. Thomas (1975). A method of assessing the abundance of butterflies in Monk's Wood National Nature Reserve in 1973. Entomologist's Gaz 26: 79-88.

Ugarte, E. and Rodricks (1960). Butterflies of Palni hills: A complementary list. Journal of the Bombay Natural History Society 57(2): 270-277.

Walpole, M.J. and I.R. Sheldon (1999). Sampling butterflies in tropical rain forest: an evaluation of transect walk method. Biological Conservation 87: 85-91.

Wynter-Blyth (1957). Butterflies of the Indian region. Bombay Natural History Society. Bombay, 523pp.

\section{ACKNOWLEDGements}

We are thankful to Dr. V.S. Vijayan Director of SACON, Coimbatore, for the encouragement, financial assistance and facilities provided for the study.

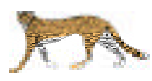

